https://helda.helsinki.fi

\title{
Special Issue on Date Palm Current Research II
}

\author{
Al-Khayri, J. M.
}

2014

Al-Khayri , J M , Jain , S M \& Johnson, D V 2014 , ' Special Issue on Date Palm Current

Research II ', Emirates Journal of Food and Agriculture , vol. 26 , no. 11 , pp. 919-920 .

http://hdl.handle.net/10138/233294

publishedVersion

Downloaded from Helda, University of Helsinki institutional repository.

This is an electronic reprint of the original article.

This reprint may differ from the original in pagination and typographic detail.

Please cite the original version. 


\title{
EDITORIAL
}

\section{Special issue on Date Palm Current Research}

\author{
J. M. Al-Khayri ${ }^{1}$, D. V. Johnson' ${ }^{2}$, S. M. Jain ${ }^{3}$ \\ ${ }^{1}$ Department of Agricultural Biotechnology, King Faisal University, Al-Hassa 31982, Saudi Arabia \\ (Email: jkhayri@kfu.edu.sa) \\ ${ }^{2} 3726$ Middlebrook Ave, Cincinnati, OH 45208, USA \\ (Email: djohn37@aol.com) \\ ${ }^{3}$ Department of Agricultural Sciences, University of Helsinki, PL-27, Helsinki, Finland \\ (Email: mohan.jain@helsinki.fi)
}

Date palm, Phoenix dactylifera L., a monocotyledonous angiosperm diploid species belonging to the Arecaceae (Palmae) family, is considered as one of the world's first cultivated fruit trees. Along with the olive and the fig, the three represent an ancient group of fruit trees closely associated with the beginnings of agriculture and the sustenance of humankind in the arid regions of the Old World.

For the last century, scientists have been engaged in research to delineate agricultural challenges, find suitable solutions, and continue to expand awareness and utilization of this majestic species. As part of an ongoing effort to provide researchers with periodic updates on date palm research, future special issues on the subject are planned, the frequency to depend upon the proliferation of relevant research results. Recently, a Special Issue on The First Date Palm and Dates Conference (held at King Abdulaziz City for Science and Technology, Riyadh, Saudi Arabia on December 4-7, 2011) was published (Emir. J. Food Agri., 2012, Volume 24, Issue 5).

This Special Issue on Date Palm Current Research provides a valuable source of current research achievements relevant to this important fruit tree crop. In addition to six review articles highlighting progress and current status of several subjects, four original research articles present the latest results obtained by scientists actively working with date palm. Aspects covered in this compilation are: Nutritional importance, Micropropagation, Abiotic and biotic challenges, Genetic resources, and Molecular biodiversity.

Date palm is mainly grown for its fruits, but the whole tree is utilized. Dates are a highly nutritious source of sugars, minerals, vitamins and antiatherogenic nutrients. Dates are used as a sweetener in numerous traditional desserts and contemporary baked goods, Manickavasagan et al. (2013) article recommends date fruits as a sugarsubstitute source in traditional foods.
Propagation of date palm is traditionally by offshoots; however, increased demands for offshoots to expand agricultural areas have necessitated the use of tissue culture. Remarkable progress has been made in date palm micropropagation since it was first achieved in the early 1970s. At present, commercial micropropagation is becoming commonplace for commercial date palm production. Researchers continue to improve this process through empirical assessment of various tissue culture factors in relation to the wide array of available cultivars. An article exemplifying these efforts is presented by Ibraheem et al. (2013) where proliferation of somatic embryogenesis of cv. Zaghlool was investigated in response to solid and liquid cultures. Culture contamination, perhaps the oldest and most complex challenge of tissue culture success, is revisited in the article by Abass (2013) who focused on microbial contaminants tissue culture laboratories in Iraq.

Another restriction of date palm tissue culture is the scarification of the tree through the excision of shoot tips for utilization as explants source. An alternative source of explants is of paramount importance when none or a low number of offshoots are available. The in vitro response of various explants is influenced by genotype and numerous culture factors. Researchers have achieved in vitro regeneration of date palm using florescence explants as a less invasive alternative. Abahmane (2013) reviewed achievements and limitations of date palm inflorescence explants.

The main date-producing countries are found in regions where extremely high temperatures, a limited water supply and saline soils represent major agricultural constraints. Date palms are resilient in the face of these adverse environmental conditions. However, fruit quality and yield are affected by soil salinity and water stress. In light of global climate warming these problems are expected to be exacerbated in the date palm 
growing regions, thus intervention strategies are needed to overcome these impending challenges. Al-Karaki (2013) has addressed in his review article about improved water utilization using mycorrhizae.

A current biotic challenge for date palm agriculture is the devastating impact of widelydisseminated pests and diseases. The most serious pest of date palm, as well as many other palm species in the world, is the red palm weevil. This aspect is well covered by Hazir and Buyukozturk (2013) highlighting the status and control methods of red palm weevil and red palm scale insects mainly focus on Turkey.

Breeding efforts to improve tolerance to abiotic as well as biotic stress conditions is of paramount importance for sustainable agriculture of date palm. Conventional date palm breeding is restricted by a long juvenile phase and high heterozygosity. Relevant to this aspect, Johnson et al. (2013) reviewed reflecting a contemporary look at the seedling date palms as a potential germplasm. Moreover, modern biotechnological approaches including in vitro embryo rescue techniques offer indispensable tools for date palm breeding through the production of interspecific hybrids. The prospect of interspecific hybridization in relation to date palm conservation and genetic improvement is reviewed by Gros-Balthazard (2013).

In support of breeding efforts, biotechnology offers effective approaches for date palm improvement and germplasm conservation and characterization. Molecular tools are being used in in different crops for studying genetic diversity, genomics, markers assisted selection and breeding. We have included two articles on the use of molecular techniques based on DNA analysis to study date palm biodiversity. Srivashtav et al. (2013) addressed genetic diversity in the Kutch region of India and El Kichaoui et al. (2013) described genotyping of date palm cultivars of the Gaza Strip of Palestine.

The Guest Editors wish to thank the contributors to this special issue. We are also grateful to the peer reviewers for their timely, thorough evaluation of manuscripts. Finally, our appreciation is extended to the Executive and Managing Editors of the Emirates Journal for Food and Agriculture for this opportunity.

\section{References}

Abahmane, L. 2013. Recent achievements in date palm (Phoenix dactylifera L.) micropropagation from inflorescence tissues. Emir. J. Food Agric. 25(11):863-874.
Abass, M. H. 2013. Microbial contaminants of date palm (Phoenix dactylifera L.) in Iraqi tissue culture laboratories. Emir. J. Food Agric. 25(11):875-882.

Al-Karaki, G. N. 2013. Application of mycorrhizae in sustainable date palm cultivation. Emir. J. Food Agric. 25(11):854-862.

El Kichaoui, A., M. A. Abu Zayed and B. M. Ayesh. 2013. Genotyping and identification of six date palm (Phoenix dactylifera L.) cultivars of the Gaza Strip by random amplification of polymorphic DNA. Emir. J. Food Agric. 25(11):916-925.

Hazir, A. and H. D. Buyukozturk. 2013. Phoenix spp. and other ornamental palms in Turkey: The threat from red palm weevil and red palm scale insects. Emir. J. Food Agric. 25(11):843853.

Ibraheem, Y., I. Pinker and M. Böhme. 2013. A comparative study between solid and liquid cultures relative to callus growth and somatic embryo formation in date palm (Phoenix dactylifera L.) cv. Zaghlool. Emir. J. Food Agric. 25(11):883-898.

Johnson, D. V., J. M. Al-Khayri and S. M. Jain 2013. Seedling date palms (Phoenix dactylifera L.) as genetic resources. Emir. J. Food Agric. 25(11):809-830.

Manickavasagan, A., T. A. Mathew, Z. H. AlAttabi and I. M. Al-Zakwani. 2013. Dates as a substitute for added sugar in traditional foods - A case study with idli. Emir. J. Food Agric. 25(11):899-906.

Muriel Gros-Balthazard. 2013. Hybridization in the genus Phoenix: A review. Emir. J. Food Agric. 25(11):831-842.

Srivashtav, V. S., C. V. Kapadia, M. K. Mahatma, S. K. Jha, S. Jha and T. Ahmad. 2013. Genetic diversity of date palm (Phoenix dactylifera $\mathrm{L}$.) in the Kutch region of India using RAPD and ISSR markers. Emir. J. Food Agric. 25(11):907-915. 